\title{
EFFECT OF SIMVASTATIN IN SERUM INTERLEUKIN-6 LEVEL IN PATIENTS WITH ACUTE ISCHEMIC STROKE
}

\author{
Maria Lettisia Meo ${ }^{1}$, Abdulloh Machin ${ }^{2}$, Didik Hasmono ${ }^{3}$ \\ ${ }^{1}$ Master Program of Clinical Pharmacy, Faculty of Pharmacy, ${ }^{2}$ Department of Neurology, Soetomo Teaching \\ Hospital Surabaya, ${ }^{3}$ Department of Clinical Pharmacy, Faculty of Pharmacy, Universitas Airlangga, Surabaya, \\ Indonesia
}

\begin{abstract}
Acute ischemic stroke is the leading cause of death and causing permanent disability in adults worldwide. In acute ischemic stroke, IL-6 levels positively correlated to more severe neurological deficits, more extensive brain damage and worse prognoses. The use of statin was associated with milder initial stroke severity, better functional outcome and lower mortality. This clinically randomized controlled trial study was aimed to analyze the serum levels of IL 6 in acute ischemic stroke patients who treated with Simvastatin $20 \mathrm{mg}$ compare to placebo. Samples were taken using consecutive sampling method from hospitalized acute ischemic stroke patients in Neurology Department of Dr. Soetomo Teaching Hospital Surabaya and Airlangga University Hospital Surabaya from August to November 2017. Total of 44 patients met the inclusion criteria, consisting of 22 patients in treatment group and 22 patients in control group. There were no significant difference in the characteristic of the patients in both groups ( $p>0.05)$. Averages of serum IL-6 in the control and the treatment group are $38.594 \pm 74.313$ and $17.760 \pm 25.253(p=0,438)$ while averages of serum IL-6 post in the control group and the treatment are $46.586 \pm 103.484$ and $15.275 \pm 17.183(p=0,589)$. There were no significant level escalation in pre and post of control group $(p=0.205)$ and also no significant level reduction in pre and post of treatment group $(p=0.411)$, while the average difference in the control group $(-7.992 \pm 78.912 \mathrm{pg} / \mathrm{ml})$ and in the treatment group $(2.485 \pm 23.738 \mathrm{pg} / \mathrm{ml})$.
\end{abstract}

Keywords: Acute ischemic stroke; IL-6; Simvastatin

\section{ABSTRAK}

Stroke iskemik akut merupakan penyebab utama kematian dan menyebabkan kecacatan permanen pada orang dewasa di seluruh dunia. Pada stroke iskemik akut, kadar IL-6 berkorelasi positif dengan defisit neurologis yang lebih parah, kerusakan otak yang lebih luas, dan prognosis yang lebih buruk. Penggunaan statin dikaitkan dengan keparahan stroke awal yang lebih ringan, hasil fungsional yang lebih baik, dan mortalitas yang lebih rendah. Studi uji klinis acak terkontrol ini bertujuan untuk menganalisis kadar IL 6 serum pada pasien stroke iskemik akut yang diobati dengan Simvastatin 20 mg dibandingkan dengan plasebo. Pengambilan sampel menggunakan metode consecutive sampling dari pasien stroke iskemik akut rawat inap di Departemen Neurologi RSUP Dr. Soetomo Surabaya dan RSU Universitas Airlangga Surabaya dari bulan Agustus sampai November 2017. Total 44 pasien memenuhi kriteria inklusi, terdiri dari 22 pasien dalam kelompok perlakuan. dan 22 pasien dalam kelompok kontrol. Tidak terdapat perbedaan yang bermakna pada karakteristik pasien pada kedua kelompok ( $p>0,05)$. Rata-rata IL-6 serum pada kelompok kontrol dan kelompok perlakuan adalah $38.594 \pm 74.313$ dan $17.760 \pm 25.253(p=0,438)$ sedangkan rata-rata pemberian IL-6 serum pada kelompok kontrol dan perlakuan adalah $46.586 \pm 103.484$ dan $15.275 \pm$ $17.183(p=0,589)$. Tidak ada peningkatan tingkat yang signifikan pada kelompok kontrol sebelum dan sesudah $(p=0.205)$ dan juga tidak ada penurunan tingkat yang signifikan pada kelompok sebelum dan sesudah perlakuan ( $p=0.411)$, sedangkan perbedaan rata-rata pada kelompok kontrol (-7,992 $\pm 78,912)$ pg/ml) dan pada kelompok perlakuan $(2,485 \pm 23,738$ pg/ml).

Kata kunci: stroke iskemik akut; IL-6; Simvastatin

Correspondence: Maria Lettisia Meo, Master Program of Clinical Pharmacy, Faculty of Pharmacy, Universitas Airlangga, Jl. Airlangga 6-8, Surabaya 60286, Indonesia. e-mail: lety_meo@yahoo.com

pISSN:2355-8393 • eISSN: 2599-056x • doi:

- Fol Med Indones. 2020;56:165-173 • Received 26 Jan $2018 \bullet$ Accepted 12 Jul 2018

- Open access under CC-BY-NC-SA license • Available at https://e-journal.unair.ac.id/FMI/

\section{INTRODUCTION}

Ischemic stroke is a general stroke happened rather than hemorrhagic stroke. It is well marked by suddenly loss of blood circulation to brain in result of thrombotic occlusion or cerebral artery occlusion. In USA, stroke is in the fourth from five leading cause of death, besides heart disease, cancer, chronic lower respiratory disease 
and injury. It is also become the second leading cause of death worldwide after heart disease, which is $11.13 \%$ from total death in the world (Neema 2015, Mozaffarian, et al 2016). National Basic Health Research (Riset Kesehatan Dasar (Riskesdas) Nasional) of 2013 shows there is growth of stroke prevalence in Indonesia which 8.3 per mil in 2007 to 12.1 per mil in 2013 (Balitbangkes 2013).

Inflammation process has a main role in the whole ischemic stroke pathogenesis. The inflammation occurs in hours after the ischemic onset, marked with molecule adhesion in blood vessel endhotel and leukocytes in the circulation to brain parenchyma. Leukocytes are out of the circulation passing through the endhotel and penetrating brain parenchyma tissue which leading inflammation reaction. Majority part of inflammation is determined by population of microglia cell. This inflammation causes secondary damage of neuron cell (Deb et al 2010, Misbach et al 2011).

Decreased blood flow to the brain in ischemic stroke is a direct reaction to the glucose and oxygen deficiency, will lead to loss of ion balance, calcium deregulations, acidosis, and excitotoxicity which become a manifest to damage cell or death cell. This event causes passive release of Danger Associated Molecular Pattern Molecules (DAMPs), which binds and activates PatternRecognition Receptors (PRR) and triggers activation of the innate immune system and initiates inflammation (Gesuete et al 2014). High-mobility Group Protein B1 (HMGB-1) is a typical DAMP molecule which initiates inflammation through Toll-Like Receptors (TLRs) such as TLR-2 and TLR-4 (Zhao et al 2015).

TLR sticking awakes the signal and triggers transcription factor like Nuclear Factor Kappa B (NF$\mathrm{kB}$ ) which promote the expressions of various proinflammation cytokine like Tumor Necrosis FactorAlpha (TNF- $\alpha$ ), Interleukin-6 (IL-6) and Interleukin-1B (IL-1 $\beta$ ) (Abbas et al 2016). However, the increase of this pro-inflammation cytokine is a disadvantage since it leads neuron death in instance (D0114 et al 2014). IL-6 is a pro-inflammatory cytokine produced by various cells including monocytes, macrophages, fibroblasts, endothelial cells, keratinocytes, mast cells, T lymphocytes, and also by microglia and astrocytes. IL-6 is a key mediator of acute phase reaction. IL- 6 level of ischemic stroke patients arises in 24 hours and reach the peak in 2-3 days after the stroke (Tarkowski et al 1995). On the other side, there is a stating that IL-6 level arises in first week after the ischemic stroke. However, some studies show IL-6 level are peaking in 10 hours in the serum meanwhile other studies show IL-6 level are peaking on between third to the seventh day after the stroke. Though, the peaking time of IL-6 apparently depends on stroke severity (Waje et al 2005, D0114 et al 2014, Waj05-Andreassen et al 2005)

Increased level of IL-6 in the first week of ischemic stroke is correlated significantly with the volume infarction on the fifth to the seventh day and clinical result at 3 months. Secondary analysis also shows a strong association between peak plasma of IL-6 and stroke severity, clinical outcomes or mortality at 12 months (Smith, et al 2004). In addition, increased level of IL-6 on the first and fifth days relates to mortality, functional disability, and performance status (in the third month and first year) in patients with acute ischemic (Syaafi, et al 2014), as well as a strong predictor of the infarct volumes and neurological deficits. Higher level of IL- 6 has a significant effect on poor outcome and mortality in 6 months after the stroke (Whiteley 2009).

Endothelial dysfunction, thrombogenesis, inflammation, oxidative stress damage and angiogenesis play an important role in ischemic pathogenesis of the brain and are targets for the prevention and treatment of ischemic stroke. Statins are inhibitors reductase 3-hydroxy-3methylglutaryl-Coenzyme A (HMG-CoA) that can improve endothelial function, modulate thrombogenesis, reduce inflammatory damage and oxidative stress, and facilitate angiogenesis far beyond lowering cholesterol level (Zhao et al 2014).

The anti-inflammatory effect of statins through the mevalonate pathway inhibits the conversion of HMGCoA into mevalonate which is a pathway in cholesterol synthesis (Bonaventura \& Liberale, 2016). The resistance of isoprenoid production causes the transduction of Rho signals to be inhibited. This leads to activation of Peroxisome Proliferator-Activated Receptor- $\alpha$ (PPAR- $\alpha$ ) and Peroxisome ProliferatorActivated Receptor- $\gamma$ (PPAR- $\gamma$ ) and inhibits activation of transcription factors of inflammation Activating Protein-1 (AP-1) and NF-kB, thus, lowering the expression of pro-inflammatory cytokines (IL-6, IL-1, TNF- $\alpha$ ) (Rasmussen et al 2001, Jingru Zhao et al 2014).

In clinical tests with simvastatin in acute ischemic stroke (AIS), Montaner et al. (2008) shows more complete cases of functional recovery after 3 months of treatment with simvastatin $40 \mathrm{mg} /$ day during the first 1 week and continued $20 \mathrm{mg}$ /day for up to 90 days, compared with the group not given simvastatin $(p<0.05)$. Significant increases were observed on day 3 of treatment, but became vulnerable to infection risk. In a review of meta-analysis, Statin use is associated with decreased inflammatory biomarkers, i.e., CRP and cytokines (IL-1, IL-6, IL-12, TNF- $\alpha$, IFN- $\gamma$ ) (Zhao et al 2014). 
Until now, in SMF Science of Neurology RSUD Dr. Soetomo Surabaya, the use of simvastatin is still limited as a lipid lowering agent in addition to three other types of statins such as pravastatin, atorvastatin and rosuvastatin. But in practice, it still refers to the established provisions in the national formulary, such as the use of atorvastatin and rosuvastatin if by consuming simvastatin the patient does not achieve the LDL reduction target. This is in accordance with the restrictions contained in the National Health Insurance $(\mathrm{JKN})$ system for the services of JKN patients (Kemenkes 2015).

Besides using in patients with hyperlipidemia, simvastatin also has a pleiotropic effect with its antiinflammatory effects as well as lipid-lowering agents. Hence, research on other biomarkers to measure the effectiveness of simvastatin administration in ischemic stroke conditions is needed. Based on this, this study was conducted to analyze the effects of antiinflammatory simvastatin in patients with acute ischemic stroke using interleukin-6 (IL-6) proinflammatory cytokine biomarkers.

\section{MATERIALS AND METHODS}

This study is part of the Influence of Simvastatin on Inflammatory Marker in Acute Ischemic Stroke (ISIM Study) study which is a randomized controlled trial clinical test of patients with acute ischemic stroke who had a stroke occurred $\leq 24$ hours before hospitalized in hospital, male and female patients $\geq 18$ years and signed informed consent. Samples were taken by consecutive sampling that is acute ischemic stroke patients who hospitalized in IRNA Medical SMF Science of Neurology, Dr. Soetomo Hospital and Universitas Airlangga Hospital in Surabaya during the period of August to November 2017 that meet the inclusion criteria. The distribution of samples to the control group and the treatment group was done by random allocation using random numbers from the computer.

A total of 44 patients who met the inclusion criteria, consisting of 22 treatment group patients and 22 control group patients were included in the study. The blood of each patient was drawn $3 \mathrm{~mL}$ from the veins on the first day of staying overnight prior to simvastatin/placebo given and on the fifth day 2 hours after simvastatin/placebo given. The blood was then incubated for 30 minutes at room temperature then centrifuged ( $1000 \mathrm{x} \mathrm{g}$ for 15 minutes) to obtain serum. Analysis of serum level was using Quanticine ELISA Human IL-6 Immunoassay Datasheet (R \& D System,
Mineapolis, USA). The data obtained were serum IL-6 levels in $\mathrm{pg} / \mathrm{mL}$.

The difference between serum IL-6 levels pre- and postsimvastatin of $20 \mathrm{mg}$ was analyzed by paired t-test for normal distributed data and the Wilcoxon signed ranks test for abnormal distributed data. Meanwhile, to compare serum IL-6 levels in both groups (intervention group and control group) was used independent t-test for normal distributed data and Mann-Whitney test for abnormal distributed data. Data processing used Statistical Package for the Social Sciences (SPSS) program.

\section{RESULTS}

A study on the effect of simvastatin given on serum IL6 levels in acute ischemic stroke patients have been done in the overstaying installation room (IRNA) of SMF Medical Science of Neurology RSUD Dr. Soetomo and Universitas Airlangga Hospital during the period August - November 2017. Prior to the research, researchers have received the approval of ethical acceptance by the Committee of Medical Research Ethics of Dr. Soetomo Hospital Surabaya based on Ethical Clearance Certificate No. 447/Panke.KKE/VII/2017 and the approval of ethical acceptance by the Ethics and Law Committee of Airlangga University Hospital based on the Ethical Passing Certificate No. 127/KEH/2017.

This study observed patient's characteristics, include gender, age, smoking history, history of disease including hypertension, diabetes mellitus, heart, stroke and therapy gained during the study (ASA, CDP cholin, metamizole, vitamin B1, B6, B12) as shown in Table 1.

Table 1 shows that the average age of acute ischemic stroke patients in both groups was 61.4 years for the placebo (control) group and 58.7 years for the treatment group (simvastatin). After the statistical tests, there were no significant difference between the two groups $(\mathrm{p}=0.452)$. In addition to age, the sexes in both groups did not differ significantly $(\mathrm{p}=0.215)$.

Some of the risk factors were found in patients includes smoking habits and the history of diseases such as hypertension, diabetes, heart and stroke. From the table above, the most common risk factors were found in both groups of patients is hypertension with percentage in control group patients $95.5 \%$ while in the treatment group $77.3 \%$. After comparison between the two groups, there was no significant difference $(p=0.082)$. 
Table 1. Patients' characteristics

\begin{tabular}{|c|c|c|c|c|}
\hline Characteristics & Placebo $(n=22)$ & $\begin{array}{l}\text { Simvastatin } \\
\quad(n=22)\end{array}$ & Total $(n=44)$ & $\mathrm{p}$ Result \\
\hline Age - average (years) & 61.4 & 58.7 & 60 & 0.452 \\
\hline \multicolumn{5}{|l|}{ Gender - amount (\%) } \\
\hline Male & $16(72.7)$ & $12(54.5)$ & $28(63.6)$ & \multirow[t]{2}{*}{0.215} \\
\hline Female & $6(27.3)$ & $10(45.5)$ & $16(36.4)$ & \\
\hline Smoking history - amount (\%) & $6(27.3)$ & $4(18.2)$ & $10(27.7)$ & 0.477 \\
\hline \multicolumn{5}{|l|}{ Disease history - amount (\%) } \\
\hline Hypertension & $21(95.5)$ & $17(77.3)$ & $38(86.4)$ & 0.082 \\
\hline Diabetes & $5(22.7)$ & $6(27.3)$ & $11(25.0)$ & 0.731 \\
\hline Heart disease & $3(13.6)$ & $3(13.6)$ & $6(13.6)$ & 1.000 \\
\hline Stroke & $6(27.3)$ & $7(31.8)$ & $13(29.5)$ & 0.744 \\
\hline \multicolumn{5}{|l|}{ Therapy - amount (\%) } \\
\hline ASA & $19(86.4)$ & $20(90.9)$ & $39(88.6)$ & 0.639 \\
\hline CDP Cholin & $15(68.2)$ & $13(59.1))$ & $28(63.6)$ & 0.536 \\
\hline Metamizole & $4(18.2)$ & $2(9.1)$ & $6(13.6)$ & 0.385 \\
\hline Vit B & $4(18.2)$ & $6(27.3)$ & $10(27.7)$ & 0.477 \\
\hline
\end{tabular}

Table 2. Statistical analysis of serum IL-6 difference in the control group and treatment group

\begin{tabular}{lccc}
\hline & Control $(\mathrm{n}=22)$ & $\begin{array}{c}\text { Treatment } \\
(\mathrm{n}=22)\end{array}$ & Significancy $(\mathrm{p})$ \\
\hline Average of Serum IL-6 Levels before & & $17.760 \pm$ & \\
$\begin{array}{l}\text { Intervention } \pm \text { SD }(\mathrm{pg} / \mathrm{ml}) \\
\text { Average of Serum IL-6 Levels after }\end{array}$ & $38.594 \pm 74.313$ & 25.253 & 0.438 \\
$\begin{array}{l}\text { Intervention } \pm \text { SD }(\mathrm{pg} / \mathrm{ml}) \\
\begin{array}{l}\text { Average of difference Serum IL-6 } \pm \text { SD } \\
(\mathrm{pg} / \mathrm{ml})\end{array}\end{array}$ & $46.586 \pm 103.484$ & 17.183 & 0.589 \\
\hline
\end{tabular}

Table 3. Statistical analysis of serum IL-6 levels changes in the control group and treatment group before and after intervention

\begin{tabular}{lccc}
\hline & Average of Serum IL-6 & Average of Serum IL-6 & \\
& Levels before Intervention \pm & Levels after Intervention \pm & Significancy $(\mathrm{p})$ \\
& $\mathrm{SD}(\mathrm{pg} / \mathrm{ml})(\mathrm{n}=44)$ & $\mathrm{SD}(\mathrm{pg} / \mathrm{ml})(\mathrm{n}=44)$ & \\
\hline Control Group & $38.594 \pm 74.313$ & $46.586 \pm 103.484$ & 0.205 \\
Treatment Group & $17.760 \pm 25.253$ & $15.275 \pm 17.183$ & 0.411 \\
\hline
\end{tabular}

For the other risk factors, there were no significant differences in the two groups of patients in the history of diabetes $(p=0.731)$, history of heart disease $(p=1.000)$, previous stroke $(p=0.744)$, smoking habit $(\mathrm{p}=0.477)$. During hospitalization, patients also received other therapies such as ASA (acetyl salicylic acid), CDP Cholin, metamizole and also vitamin B1, B6 and B12. These therapies may affect pro-inflammatory markers levels so they can create bias. However, after statistically comparing, there was no significant difference between the two groups.

Blood sampling for each patient in both control and treatment groups to measure the serum Interleukin 6 levels was performed twice: on the first day of hospitalization (before placebo/simvastatin) and on the fifth day of hospitalization ( 2 hours after simvastatin/placebo).

The research brings out that the range of serum IL-6 levels in the control group before the intervention (pre) is $2.557-260.450 \mathrm{pg} / \mathrm{ml}$ and after intervention (post) is $0-437,950 \mathrm{pg} / \mathrm{ml}$. Serum IL-6 levels are increased in 12 patients $(54.54 \%)$ of the control group after placebo for 5 days. However, serum IL-6 levels are decreased in 9 patients $(40.90 \%)$ and 1 patient $(4.54 \%)$ with no change in serum IL-6 levels after placebo for 5 days. In the treatment group, range of serum IL-6 levels before the intervention (pre) is $0-115,336 \mathrm{pg} / \mathrm{ml}$, and after intervention (post) is $0-53.937 \mathrm{pg} / \mathrm{ml}$. There are 8 
patients $(36.36 \%)$ with decreased serum of IL-6 levels and 12 patients $(54.54 \%)$ who have increased and 2 patients $(9.09 \%)$ with no change of serum of IL-6 level after consuming simvastatin for 5 days. The statistical analysis of serum IL-6 levels difference in the control and treatment groups as well as changes in serum IL-6 levels before and after intervention can be seen in Tables 2 and 3 .

Table 2 shows that the average serum IL-6 levels before the intervention in the control group is in the range $38.594 \pm 74.313 \mathrm{pg} / \mathrm{ml}$, it is higher compared with the treatment group with a range of $17.760 \pm 25.253 \mathrm{pg} / \mathrm{ml}$. However, after the Mann-Whitney test, it is found that the difference is not statistically significant with $p>0.05$ $(\mathrm{p}=0.438)$. After intervention, the average serum IL-6 levels in the treatment group is in the range $15.275 \pm$ $17.183 \mathrm{pg} / \mathrm{ml}$, it is lower than the control group with range $46.586 \pm 103.484 \mathrm{pg} / \mathrm{ml}$. After the Mann-Whitney test it is found that the difference is not statistically significant with $\mathrm{p}>0.05(\mathrm{p}=0.589)$.

When compared between before and after intervention in the same group (Table 3) it is found that the average serum IL-6 levels in control group increased from the rate of $38.594 \pm 74.313 \mathrm{pg} / \mathrm{ml}$ to $46.586 \pm 103.484$ $\mathrm{pg} / \mathrm{ml}$, but statistically it does not show the meaningful difference $(p=0.205)$. While in the treatment group, it decreased from the average rate of $17.760 \pm 25.253$ $\mathrm{pg} / \mathrm{ml}$ to $15.275 \pm 17.183 \mathrm{pg} / \mathrm{ml}$, but this decrease does not show meaningful significance $(p=0.411)$. In the average value of serum IL-6 levels of the control group, negative (-) result is gained, this indicates that the serum IL-6 levels before the intervention (pre) in control group patients have increased, while in the treatment group obtained positive value, this indicates that serum IL-6 levels before the intervention (pre) decrease.

\section{DISCUSSION}

The aim of this study is to analyze the effect of simvastatin consumption toward changes in IL-6 levels as one of the biomarkers in the inflammatory process that occurs in acute ischemic stroke condition. The study was conducted in IRNA Medical SMF Science of Neurology, Dr. Soetomo Hospital and Universitas Airlangga Hospital Surabaya during the period of August to November 2017. Up to the end of the study, there were 44 patients consisting of 22 control group patients and 22 treatment group patients. The research data are processed based on characteristic data and serum of IL-6 levels of acute ischemic stroke patients from each study group. Data are presented in tables and figures and statistical analyzes are performed using the Mann-Whitney test to determine the ratio of serum IL-6 levels between the two groups (control and treatment) and the Wilcoxon test to determine differences between pre- and post- levels in each group. Before performing Mann-Whitney Test and Wilcoxon test, KolmogorovSmirnoff Normalities and Saphiro-Wilk Normalities were used and the result were not normally distributed $(\mathrm{p}<0.05)$.

Patient's demographic data covering gender, age, smoking history, and history of hypertension, diabetes, heart disease, and stroke, and history of therapy are shown in Table 1. It appears that male patients $(63.6 \%)$ accounted more than female $(36.4 \%)$ and the average age is 60 years. This is consistent with the results of the study suggesting that male are 1.25 times more likely to have a stroke than female (Samai \& Martin-Schild 2015). The prevalency of ischemic stroke remains stable in individuals aged 18 to 44 and 45 to 64 years but has a tendency to decline at age $\geq 65$ years (Benjamin et al 2017). Other study has also suggested that female experience the first stroke attack in older age than male. In 98 studies covering 19 countries and 5 continents, the average age of stroke that ever existed was 72.9 years in female compared with 68.6 years in male (Samai \& Martin-Schild 2015).

In addition to unmodifiable risk factors such as age and sex, there are also some modifiable risk factors such as smoking habits, hypertension, diabetes mellitus, heart disease, and previous history of stroke. From table 1 above, it can be concluded that hypertension is the most common risk factor in both groups $(86.4 \%)$, with more male group (26 people) than female (12 people). According to statistical calculations with age variables, it turns out that hypertension has a stroke risk of 3 to 1 for male, and female 2.9 times more frequent than those with elderly with normal blood (Misbach et al 2011). A decrease of TDS to $<130 \mathrm{mmHg}$ also proved to reduce the incidence of recurrent stroke by $20 \%$ (Mozaffarian et al 2016). An increase in blood pressure may lead to endothelium dysfunction. This endothelium is a cell that covers the inside of a vein that has an important role in the regulation of vascular hemostasis. If endothelium dysfunction occurs, it will increase proinflammatory, protrombotic, expression of adhesion molecules and cholesterol deposition. This can trigger the process of atherosclerosis and thus cause ischemic (Leopold, 2013).

In addition to hypertension, diabetes mellitus, heart disease, previous stroke history and smoking habits, influence the stroke inflammatory process. Smoking may increase the risk of ischemic stroke 2 times higher and 2 to 4 times higher in hemorrhagic stroke. $12 \%$ to $14 \%$ of total deaths in stroke have a relationship with smoking. Smoking affects the formation of thrombus in 
the atherosclerotic artery and chronic exposure of cigarettes may increase the process of vascular atherosclerosis (Goldstein et al 2011). Carbon monoxide (CO) from cigarettes can also reduce the amount of oxygen carried by the blood so that it can trigger tissue hypoxia and then will cause damage to vascular endothelial cells (Mitrovic 2014, Yueniwati 2015).

Some of the therapies gained in patient rooms during the study (ASA, CDP Cholin, metamizole, vitamin B1, B6 and B12) may influence inflammatory cytokines as well. The antiplatelet Aspirin (ASA) effect irreversibly inhibits cyclooxygenase-1 thrombocyte (COX-1), which results in decreased platelet activation of thromboxane. ASA is a nonsteroidal anti-inflammatory drug (NSAID) that works by inhibiting cyclooxygenase pathways through arachidonic acid metabolism, which at high doses (1g) as anti-inflammatory, but at low doses of 75 $150 \mathrm{mg}$ have cardioprotective and antiplatelet effects by inhibiting formation of thromboxane (Tx) A2. Furthermore, it is said that low-dose aspirin 75-150mg can reduce the innate immune response in humans by triggering 15-epi-lipoxin A4 of endothelial COX2 so it has anti-inflammatory properties (Morris et al 2009). Metamizole has an anti-inflammatory effect by inhibiting cyclooxygenase enzymes thereby reducing prostaglandin synthesis (Cazacu et al 2015). CDPcholine can increase phosphatidylcholine levels by suppressing the stimulation of phospholipase A2 (PLA2) which is an inflammatory mediator (Adibhatla \& Hatcher 2005). The effect of vitamin $B$ on inflammation is related to its effect on homocysteine. Increased levels of homocysteine are associated with low levels of vitamin B6 and vitamin B 12 in the blood. The condition of hyperhomocysteinemia increases oxidative stress and damage to vascular endothelial cells and reduces the production and bioavailability of nitric oxide (a strong relaxation factor) in the endothelium and triggers an inflammatory response (Folsom et al 2003, Hariri et al 2013).

Eventhough can influences inflammatory process, but there is no direct link between IL- 6 and the abovementioned drugs. To anticipate the existence of differences of risk factor characteristics in both groups, statistically different test is used, the result shows no significant difference between the two groups $(\mathrm{p}>0.05)$, so it can be accepted that the difference in the results of this study is not influenced by risk factors and the above-mentioned therapies.

In this study, it is found that serum IL-6 levels before intervention in both groups have mixed results. In Figure 1 and 2 it can be seen that serum levels of IL-6 control group before the intervention (pre) were 2.557 $260.450 \mathrm{pg} / \mathrm{ml}$, and after intervention (post) was 0 -
$437.950 \mathrm{pg} / \mathrm{ml}$. Meanwhile, the range of serum IL-6 levels in the treatment group before the intervention (pre) is $0-115.336 \mathrm{pg} / \mathrm{ml}$ and after intervention (post) is $0-53.937 \mathrm{pg} / \mathrm{ml}$. The measurement of serum IL-6 levels before intervention was done to know the initial value of serum IL-6 in each patient. Several outcomes from previous studies suggest that serum IL-6 levels greatly vary among individuals so it is not possible to establish a definite serum IL-6 level and therefore the measurement of initial value of serum IL-6 levels is necessary as a common reference in acute ischemic stroke patients.

Table 2 shows the difference in mean serum levels of IL-6 before and after intervention in the control and treatment group. The average of serum IL-6 levels before intervention in the control group is in the range $38,782 \pm 74,216 \mathrm{pg} / \mathrm{ml}$, it is higher than the treatment group with the range of $17,76025,253 \mathrm{pg} / \mathrm{ml}$. The large standard deviation (SD) at the average serum IL-6 levels before and after this intervention reflects that the measured data has large variations. However, after the Mann-Whitney test it is found that the difference is not statistically significant with $p>0.05 \quad(p=0.438)$. Variations of serum IL-6 levels in each of these patients are a cause of the relation of serum IL-6 on the size of the lesions in the brain. Increased production of proinflammatory cytokines (TNF- $\alpha$, interleukin (IL) $1 \beta$, IL-6) correlates significantly with the vast of lesion size in animal models and worse clinical outcomes. The increase of this serum IL-6 levels is associated with worsening neurologic symptoms, increased infarct size and poor functional outcome (D0114 et al 2014). Cut point off IL-6 is $6.47 \mathrm{pg} / \mathrm{ml}$ (Shenhar-Tsarfaty et al 2010). In this study, serum IL-6 levels of 10 patients in the control group $\mathrm{ml}$ and of 13 patients in the treatment group are found greater than $6.47 \mathrm{pg} / \mathrm{ml}$. ShenharTsarfaty et al., states if IL-6 above $6.47 \mathrm{pg} / \mathrm{ml}$ during the acute phase predisted subsequent non-survival $(p=0.006)$. In another study of Smith et al showed that peak plasma IL- 6 concentration $>30 \mathrm{pg} / \mathrm{ml}$ in the first week after an ischemic stroke were associated with increased mortality at 12 months. ). In this study, serum IL-6 levels of 3 patients in the control and the treatment groups are found greater than $30 \mathrm{pg} / \mathrm{ml}$. However, in this study, the vast of infarct, NIHSS scores and outcome clinics of patients were not observed.

After the intervention, the average of serum IL-6 levels in the treatment group is in the range $15.928 \pm 16.710$ $\mathrm{pg} / \mathrm{ml}$ lower than the control group with the range $46.586 \pm 103.484 \mathrm{pg} / \mathrm{ml}$. After the Mann-Whitney test it is found that the difference is not statistically significant with $\mathrm{p}>0.05(\mathrm{p}=0.589)$. 
In comparison between before and after intervention in the same group, it is found that of 22 patients in the control group, serum IL-6 levels of 12 patients have increased $(54.54 \%)$ while 9 patients have decreased $(40.90 \%)$ and 1 of patients $(4.54 \%)$ has no change in serum of IL-6 levels. The average of serum IL- 6 levels before intervention increased from $38.594 \mathrm{pg} / \mathrm{ml}$ to $46.586 \mathrm{pg} / \mathrm{ml}$ after intervention. But, statistically, the increasing serum IL-6 levels do not show a significant difference $(p=0.205)$. The decrease in serum IL-6 levels is due to the severity of the stroke can determine the survival time and the increase in serum IL-6 levels (D0114 et al 2014). This study conducts no variations of length of study time, only on the first and fifth days, therefore a further study of longer or shorter duration is needed to add information on variation in serum IL-6 levels in acute ischemic stroke.

In the treatment group, there is 8 patients with decreasing serum IL-6 levels $(36.36 \%), 12$ patients with increased serum IL-6 level $(54.54 \%)$ and 2 patients $(2.09 \%)$ who have no change serum of IL-6 levels after consuming simvastatin for 5 days. In comparison between serum IL- 6 levels before and after intervention, there is a degression from $17.760 \mathrm{pg} / \mathrm{ml}$ to 15.275 $\mathrm{pg} / \mathrm{ml}$, but this degression shows no significant significance $(\mathrm{p}=0.411)$. The increased serum IL-6 levels after consumption of simvastatin $20 \mathrm{mg}$ on the fifth day may be due to drug interactions between phenytoin and simvastatin. Serum IL-6 levels of patient with code $22 \mathrm{~A}$ increase from $11.448 \mathrm{pg} / \mathrm{ml}$ to $25.102 \mathrm{pg} / \mathrm{ml}$. This patient has a history of $3 \times 100 \mathrm{mg}$ phenytoin use due to post traumatic epilepsy and hospitalized in Seruni A. in the next overstay, the patient received Phenitoin $3 \times 100$ mg (iv) therapy because of the diagnosis of epilepsy. Simvastatin is metabolized by CYP3A4 isoenzyme, whereas phenytoin is a potent CYP3A4 isoenzyme inducer which can affect simvastatin metabolism. This causes simvastatin to be ineffective or decrease its effectiveness as the drug free level in the body decreases (Malloy M \& Kane J, 2015; Suharjono, 2017).

This increase in serum IL-6 levels may also a result of heat shock proteins (Hsp70) activation in extracellular. In ischemic stroke conditions, besides causing passive release of Danger Associated Molecular Pattern Molecules (DAMPs), Hsp70 is also released. Hsp70 can interact with macrophages, microglia, and dendritic cells. Hsp70 forms ligands with Toll-like receptors (TLRs) 2 and 4 thereby causing activation transcription factor of Nuclear Factor Kappa B (NF-kB), which induces production of pro-inflammatory cytokines such as IL-6 (Kim \& Yenari 2013).
A Meta-analysis shows that the use of statins is associated with mild stroke severity, good functional outcomes and lower mortality (Hong \& Lee, 2015). Tuttolomondo, et al, (2016) suggests the use of highdose statins (atorvastatin) $80 \mathrm{mg}$ for 7 days in acute ischemic stroke patients, proving a decrease in serum TNF- $\alpha$, IL-1 $\beta$ and IL-6 inflammatory markers $(\mathrm{p}<0.05)$. Similarly, a recent study shows that more aggressively statin therapy is associated with better long-term functional outcomes of the patients with acute ischemic stroke rather than less aggressive statin therapy (Fang et al 2017).

Various types of high-dose statins generally have antiinflammatory effects. However, the use of high-dose statins should be considered as it may cause undesirable side effects. In this case, hydrophilic statins like rosuvastatin, less toxic when compared with lipophilic statins such as atorvastatin and simvastatin, due to first pass effect on the liver. In addition, although lipophilic statins easier to penetrate the blood-brain barrier, and potentially provide a protective effect on the nerves but the use of statins at high doses can cause toxic effects (Bonilla \& Campos, 2012). During the study, the researcher found no side effects of simvastatin on study recipients such as, increased activity of serum transaminase to liver and muscle disorders (myalgia, myopathy, and rhabdomyolysis).

From the results of this study, it can be concluded that giving simvastatin $20 \mathrm{mg}$ for 5 days can decrease serum IL-6 level when compared with control group in acute ischemic stroke patient, although it is not statistically significant.

\section{CONCLUSION}

The use of simvastatin $20 \mathrm{mg}$ may decrease serum IL-6 levels in acute ischemic stroke patients but statistically not significant.

\section{ACKNOWLEDGMENT}

The writers are grateful to the Director of Dr. Soetomo Hospital and Director of Universitas Airlangga Hospital, Surabaya, Head and staffs of SMF Science of Neurology Dr. Soetomo Hospital and Universitas Airlangga Hospital. The writers are also grateful to the Dean of the Faculty of Pharmacy, Universitas Airlangga, Head and staffs of the Clinical Pharmacy Master Program, Faculty of Pharmacy, Universitas Airlangga, Surabaya. 


\section{REFERENCES}

Abbas AK, Lichtman AH, Pillai S (2016). Imunologi Dasar Abbas "Fungsi Dan Kelainan Sistem Imun". 5th ed. Singapore, Elsevier

Adibhatla RM, Hatcher J (2005). Cytidine 5'Diphosphocholine (CDP-Choline) in stroke and other CNS disorders. Neurochem Res 30, 15-23

Balitbangkes (2013). Riset Kesehatan Dasar, Jakarta, Kementrian Kesehatan Republik Indonesia

Benjamin EJ, Blaha MJ, Chiuve SE, Cushman M (2017). American Heart Association - Heart Disease and Stroke Statistics. Circulation 135, 229-268

Bonaventura A, Liberale L (2016). Update on inflammatory biomarkers and treatments in ischemic stroke. International Journal of Molecular Sciences, 153

Bonilla L, Campos M (2012). Evidence for the efficacy of statins in animal stroke models: a meta-analysis. Journal of Neurochemistry 122, 233-243

Cazacu I, Mogosan C, Loghin F (2015). Safety issues of current analgesics: an update. Clujul Medical 88, 128136

D0114 DN, Barr TL, Simpkins JW (2014). Cytokines: their role in stroke and potential use as biomarkers and therapeutic targets. Aging and Disease 5, 294-306

Deb P, Sharma S, KH (2010). Pathophysiologic mechanisms of acute ischemic stroke: an overview with emphasis on therapeutic significance beyond thrombolysis. Elsevier, 197-218

Fang J-x, Er-qiang F, Wang W, Liu Y, Cheng G (2017). The efficacy and safety of high-dose statins in acute phase of ischemic stroke and transient ischemic attack: a systematic review. Springer, 1-9

Folsom AR, Desvarieux M, Nieto JF, Boland LL (2003). B vitamin status and inflammatory markers. Atherosclerosis. Elsevier 169, 169-174

Gesuete R, Kohama, SG, Stenzel-Poore M (2014). Tolllike receptors and ischemic brain injury. American Association of Neuropathologists, 378-386

Hariri M, Maghsoudi Z, Darvishi L, Askari G, Hajis M (2013). B vitamins and antioxidants intake is negatively correlated with risk of stroke in Iran. International Journal of Preventive Medicine 4, 284289

Hong KS, Lee JS (2015). Statins in acute ischemic stroke: a systematic review. Journal of Stroke, 172, 282-301

KEMENKES (2015). Keputusan Menteri Kesehatan Republik Indonesia tentang Formularium Nasional. Jakarta, KEMENTERIAN KESEHATAN REPUBLIK INDONESIA

Kim JY, Yenari MA (2013). The immune modulating properties of the head shock proteins after brain injury. Anatomy \& Cell biology 46, 1-7
Malloy MJ, Kane JP (2015). Agent used in dyslipidemia. In K. B, M. S, \& T. A, Basic \& Clinical Pharmacology 13th Ed. New York, McGraw-Hill Companies, p 619-634

Misbach J, Soertidewi L, Jannis, J (2011). STROKE, Aspek Diagnostik, Patofisiologi, Manajemen. Jakarta, FKUI

Montaner J, Chacon P, Krupinski J (2008). Simvastatin in the acute phase of ischemic stroke: a safety and efficacy pilot trial. European Journal of Neurology 15, $82-90$

Mozaffarian D, Benyamin EJ, Go AS, Arnett DK, et al (2016). Herat disease and stroke statistics - 2016 update, a report from The American Heart Association Statistics Commitee and Stroke Statistics Subcommitee Circulation. Circulation, 1-323

Neema K (2015). The science of ischemic stroke: pathophysiology \& pharmacological treatment. International Journal of Pharma Research \& Review, 65-84

Rasmussen LM, Hansen PR, Nabipour MT, Olesen P (2001). Deverse effects of inhibition of 3-hydroxy-3methylglutaryl-CoA reductase on the expression of VCAM-1 and E-selectin in endothelial cells. Biochemical Journal, 363-370

Samai AA, Martin-Schild S (2015). Sex differences in predictors of ischemic stroke: current perspectives. Dove Press Journal 11, 427-436

Shenhar-Tsarfaty S, Assayag BE, et al (2010). Interleukin-6 as an early predictor for one-year survival following an ischaemic stroke/transient ischaemic attack. World Stroke Organization International Journal of Stroke 5, 16-20

Smith CJ, Hedley C, Hedley (2004). Peak plasma interleukin-6 and other peripheral markers of inflammation in the first week of ischaemic stroke correlate with brain infarct volume, stroke severity and long-term outcome. BMC Neurology 4, 1-8

Smith WS, English JD, Johnston CS (2013). Cerebrovascular Diseases. In D. L. Longo, D. L. Kasper, L. J. Jameson, A. S. Fauci, S. L. Hauser, \& J. Loscalzo, HARRISON'S Neurology In Clinical Medicine, 3rd Ed. New York, McGraw-Hill Education, p 256-273

Suharjono. (2017). Orasi ilmiah "kajian polifarmasi dari aspek interaksi, efektifitas dan keamanan obat". Surabaya, Airlangga University Press

Syaafi S, Sharifipour E, SA (2014). Interleukin-6, a reliable prognostic factor for ischemic stroke. Iranian Journal of Neurology, 70-76

Tarkowski E, Rosengren L, et al (1995). Early intrathecal production of interleukin- 6 predicts the size of brain lesion in stroke. Stroke 26, 1393-1398

Tuttolomondo A, Domenico DR, Rosaria P, Carlo M, Valentina A, Vittoriano D, Irene S (2016). Early highdosage atorvastatin treatment improved serum 
immune-inflammatory markers and functional outcome in acute ischemic strokes classified as large artery atherosclerotic stroke a randomized trial. Medicine 95, 3-11

Waj05-Andreassen, Krakenes J, Ulvestad U, Thomassen L, et al (2005). IL-6: an early marker for outcome in acute ischemic stroke. Acta Neurologica Scandinavica, 360-365

Whiteley (2009). Inflammatory markers and poor outcome after stroke: a prospective cohort study and systematic review of interleukin-6. PLoS Medicine, 112

Zhao HT, et al (2015). Role of necroptosis in the pathogenesis of solid organ injury. Nature Publishing Group, 1-10

Zhao JJ, Zhang X, Dong L, Wen Y (2014). The many roles of statins in ischemic stroke. Current Neuropharmacology, 564-574 